\title{
CLASSIFIED LIST OF BOOKS IN THE URDU LANGUAGE SUITED TO MOSLEM READERS
}

The Urdu language grew up with the Mohammedan conquest of India. It was the lingua Franca for all business purposes in North India. The English Government has adopted Urdu and the Persian character of the language for all its courts and departmental offices. It is taught in all the primary and grammar schools, together with the Persian language as a classic. This is the language and character for the literature published for Moslems in the Punjab and a large part of the United Provinces of Agra and Oudh, and the Mohammedans themselves publish their newspapers and general literature in Persian Urdu. For this reason the missionaries have used this language and character for all publications addressed to Mohammedans. The Bible and all Scripture portions are also printed in this language and character.

For Christians, the Roman character has been widely used, but many prefer the Persian character. The number of people who use the Urdu language is generally estimated at $100,000,000$; but the literates capable of reading Persian Urdu may be estimated at no more than 5,000,000. This represents a very large portion of the Moslem people in India. I cannot now give the official statistics on this point.

This language is the medium through which the Gospel can be brought to Moslems in North and West India. The publishing societies-Bible, Tract and Book Societieshave been publishing extensive literature in this language and character for three-quarters of a century. Mission and private presses in Ludhiana, Lahore, Amritsar, Allahabad, Lucknow, Agra and elsewhere are busy printing 
and publishing in this language. Scores of books and tracts have gone out of print where new and better tracts and books have been written by men whose knowledge of Islam has enabled them to understand the thoughts of the people and so at once to avoid offending the reader by unjust and unnecessary offensive statements and at the same time to present the Truth in a way to attract the Moslem reader.

I shall now give a summary of the most important publications available for use among Moslems. (These are all printed in the Persian character.)

\section{Lives and Studies of Christ}

3. Hayátúl Masih (Life of Christ) by Rev. Talib-ud-Din, B. A., pp. 238, 8vo. Illustrated.

2. Isa ki Sirat (The Character of Christ). Bushnell, pp. 40, 8vo.

3. Masih ka Namuna (Image of Christ), Stalker, p. 288, 8 vo.

4. Masih ki Talim (Teaching of Christ), James Robertson, pp. 319, 8 vo.

5. Tawarikh u'l Masih (A History of Christ) by Dr. Maulvi Imadud-Din, 2 vols., pp. 87 and 140,8 vo.

6. Yisu Masih si Giriftári aur Maut. (The Arrest and Death of Jesus Christ), Stalker, pp. 308, 8vo.

7. Zinda Masih aur Anajil-i-Arba (The Living Christ and the Four Gospels) Dale and translated by Rev. Tálib-ud-Din, pp. 232, 8vo.

8. Hayát-i-Paulus (Life of St. Paul), Stalker, translated by Rev. Canon I. Ali Bakhsh, pp. 112, 8vo.

9. Kawa'if-us-Saha'if (The Nature of the Books) by Rev. Maulvi Imad-ud-Din, D. D., pp. 198, 8 vo.

so. Masihi Mazhab ke Ibtidai Halat (The Beginnings of Christianity) pp. 135, 8vo.

1I. Tahqiq-i-Baibal (Investigation of the Bible) by Marcus Dodds, translated by Rev. Tálib-ud-Din, pp. 154, 8 vo.

12. Tulu i Aftáb i Sadaaqát (Rising of the Sun of Righteousness) pp. 172, 8vo.

\section{TheOLOGY-Dogmatic AND Doctrinal}

13. Masihi Din ki Usuli Báten (Fundamentals of the Christian Faith) Bishop Moule. (Outline of Christian Doctrine, pp. 166, 8vo.

14. Mu'jizat-j-Masih (Miracles of Christ), by Rev. Talib ud Din, pp. 322, 8vo.

I5. Muqaddama-i-Mu'jizat-i-Masih (Introduction to the Miracles of Christ) by Rev. Talib-ud-din, B. A., pp. 107, 8vo.

16. 'Tasdiqi Kitab (Verification of the Book) pp. $31,8 \mathrm{vo}$.

17. Tashrihul Taslith (An Exposition of the Trinity) D. M. Thomas, pp. 212, 12mo.

18. Masihi ka 'Aqida (The Faith of a Christian, Bp. Gore, translated by L. Chandu Lál, pp. 164, 8vo. 


\section{Apologetics-Evidence of Christianity}

19. Bailbal aur Ségar Kutúb i Muqqaddiso (The Bible and other Sacred Books), by M. L. Rallia Ram, pp. 56, I6mo.

20. Hal-i-Mushkilát (Solution of Difficulties), by Prof. J. Orr, translated. 2 vols., pp. 200 and II 4,8 vo.

21. Haqiqat-i-Masih (The Faith of Christ), Rev. Talib-ud-Din, B. A. pp. I68, 8vo.

22. Mas'ala-i-Kaffara (Doctrine of Atonement), by Rev. J. Qalandar, pp. 13, 8vo.

23. Tajassam ka Mas'ala (Doctrine of Incarnation of Christ), Rev. J. Qalandar, pp 22, 8vo.

24. Najat ki Talim (Doctrine of Salvation), Rev. Canon Hooper, D. D. Translated by Rev. Talib-ud-Din, pp. 228, 8vo.

25. Pesh Khabr-i-an-Masih ke haqq men (Prophecies concerning Christ), pp. 68, 8vo.

26. Tuhfatúl Ulama (A gift for the learned), Rev. A. Broadhead, D.D., pp. 8o, 8vo.

27. Yisu Masih Kaun tha (Who was Jesus Christ), Norman Macleod, translated by Prof. Muhammad Ismail, pp. 40, 8vo.

28. Abdúl Masih Wald Ishaq Kandi (The Apology of Al Kandi), translated from the Arabic by Rev. Imad-ud-Din, pp. 204, 8vo.

29. Al Masihiyat wa'l Islám (Christianity and Islam), Rev. J. Qalandar, pp. 198, 8vo.

30. Al Quran (A new translation into Urdu by Rev. Ahmad Shah, pp. 508, 8vo.

31. Aqaid-i-Islamiya (The Faith of Islam), by Canon E. Sell, translated by M. Shafqatallah, pp. 291, 8vo.

32. Asmar-i-Shirin (Sweet Firstfruits), translated from the Arabic, pp. 270, $16 \mathrm{mo}$.

33. Dáwat-i-Islam (An Invitation to Islam), Dr. Wm. Muir's "Moslems Invited to Read the Bible," translated by Rev. J. David and S. Nihal Singh, pp. 56, 8vo.

34. Din-i-Islam (Faith of Islam), by Rev. E. M. Wherry, D. D., translated by Prof. Muhammed Ismail, B. A., pp. 52, $12 \mathrm{mo}$.

35. Din-i-Islam aur us ki Tordid oz ru-i-Islam, by Rev. E. M. Wherry, D. D., translated by Prof. Muharnmed Ismail, B. A., pp. 32. 12mo.

36. Fasahutu'l Quran (The Eloquence of the Quran, by M. Akbar Masih, pp. I80, 8vo.

37. Ganjúna-i-Islam (Treasury of Islam), by Rev. E. M. Wherry, D. D., (Roman Urdu), pp. 146, 8vo. (Text Book).

38. Guldasta-i-Isrár-i-Ilahi (A Nosegay of Divine Mysteries), by Bishop Lefroy, pp. 87, 8vo.

39. Hallul Ashkal (Solution of Difficulties), by Dr. Pfander, (Reply to Moslem Objections), pp. I62 and pp. 60, 8vo.

40. Hidayat ul Mumtarin (Guidance to Doubters), by Rev. E. M. Wherry, D. D., 8vo.

4I. Hidayat ul Muslimin (A Guide to Moslems), by Rev. Imad-udDin, D. D., pp. 390, 8vo.

42. Injil-i-Barnabas (The Gospel of Barnabas) by Salim Abdul Ahd and Rev. W. H. T. Gairdner, translated by Prof. Muhammad Ismail, B. A., pp. 45, $\mathrm{j} 2 \mathrm{mo}$.

43. Injil-i-Daud (The (jospel of David), by the Rt. Rev. Bishop French, pp. 350, 8vo.

44. Injil ya Quran (The Bible or the Quran), by Rev. G. L. Thakur Das, pp. I84, 8vo. 
45. Islam men Masih (Christ in Islam), by Rev. W. Goldsack, translated by Prof. Muhammad Ismail, B. A., pp. 45, $12 \mathrm{mo}$.

46. Khuda-i-Islam (The God of Islam), by Rev. W. Goldsack, translated by Prof. Muhammed Ismail, B. A., pp. 45, I $2 \mathrm{mo}$.

47. I'tirazul Muslimin ma' Jawabat (Moslem Objections with answers) by Dr. St. Clair Tisdall, translated by Rev. Ahmad Shah, pp. I 48,8 ro.

48. Khwan-i-Aql (Food for Reflection), by Abd-i-Isa (Dr. Koelle), translated by Prof. Muhammad Ismail Khan, B. A., pp. 136, 8vo.

49. Miftah-ul-Asrar (The Key to Mysteries), Dr. Pfander, pp. 84, 8vo. On Divinity and Holy Trinity.

50. Miftah'ul Quran (A key to the Quran) Part I Concordance, pp. 266, 410; Part il Glossary pp. Iog 4vo, Arabic and English, by Rev. Ahmed Shah. Also by the same author Miratul Quran (A Mirror of the Quran), pp. III, 8vo.

51. Mizanu'l Hagq (The Balance of Truth), Dr. Pfander; revised by Dr. St. Clair Tisdall, pp. 404,8 vo.

52. Nabi-i-Ma'sum (The Sinless Prophet) by Rev. E. M. Wherry, D. D., pp. 24, 8vo.

53. Niyaz-Nama (A Respectful Letter, by Maulvi Safdar Ali, E. A. C., pp. 282,8 ro. (An apology pro fide sua.)

54. Tariq-i-Najat (The May of Salvation), by Mr. Muhammad Hanif, pp. 122, I6mo.

55. Risala-i-Zainab-i-Muhammediya (Tract on the sinfulness of Mohammed), by Rev. G. L. Thahur Das, pp. 24, 12 mo.

56. Shahadat-i-Quran Bar Kutub-i-Rabbani (Testimony of the Quran to the Divine Books), Sir. Wm. Muir, translated by Rajah Shiv. Prasad, pp. 172,8vo.

57. Taqliat ul Ta'liqat (Eradication of the Taliqat-a Reply to Taliqat. pp. 100,8 vo.

58. Tariq il Hayat (The Way of Life), Rev. Dr. Pfander, pp. I66, 8ro.

59. Tasawur-i-Khuda (The idea of God), comparing Moslem and Christian ideas of God, by Rev. J. Qalandar, pp. 66, 8vo.

6o. Tawarikh-i-Muhammadi (A History of Mohammed), by Dr. Imad-ud-Din, pp. is7, 8vo. (Based on Moslem Tradition).

61. Tawil ul Quran (Interpretation of the Quran) by Akbra Ismail, pp. 88, 8vo.

62. U'du Quran (The Quran in Urdu), by Rev. Imad-ud-Din, pp. 307,8 vo.

63. Waqiat-i-Immadiya (Incidents in the life of Maulivi Imad-ud-Din with reasons for his Christian belief), I6mo.

64. Yanabi ul Islam (The Source of Islam), Rev. W. Goldsack, pp. 58, I 2 mo., translated by Prof. Muhammad Ismail, B. A.

65. Yanabi-ul-Quran (The Origin of the Quran), Rev. W. Goldsack, translated by Prof. Muhammad Ismail, B. A., pp. 58, $12 \mathrm{mo}$.

66. Abtal-i-Mirza yane Zarbat-i-Isawi (Refutation if Mirza or the Christian Blow), by Mr. Akbar Masih, pp. I54, 8vo.

67. Minarat ul Baiza (The Shining Lighthouse), by Mr. Akbar Mesih refuting claims of Mirza Ghulam Ahmad of Qadian), pp. 4b, 8vo.

68. Taftish ul Auliya (Researches about Saints), by Rev. Dr. Imadud Din, pp. I67, 8vo., on Origin of Sufi Saints.

69. Tauqid ul Khivalat (A criticism of thoughts, by the Rev. Dr. Imad-ud-Din. This book is a series of tracts intended to refute the naturalistic form of Islam put forth by Sir Sayed Ahmad Khan, C. S. I. 
70. Tauzin-ul-Aqwal (Weighing of Utterances) by Dr. Imad-ud-Din (A Criticism of Mirza Ghulam Ahmad's Teachings.)

71. Maulvi Paulus (How Maulvie Abdul Haqq became a Christian), pp. $16,12 \mathrm{mo}$.

72. Bahut Beshqunat 'Itr ki Shishi (A Memoir of W. W. Borden by Dr. W. St. Clair Tisdall, pp. 34, $12 \mathrm{mo}$.

73. Taliban-i-Haqq (Seckers of Truth), Dr. Farrar, translated, pp. 200,8 vo.

74. Mashriqki Nabud Shuda Tahzib (Extinct Civilization of the East), R. E. Sanderson, M. A., translated, pp. 108, 16mo.

75. Misr ki Kahfiyat (Transformation of Egypt), Lord Cromer, translated by Mr. Fazl, pp. 422, 8vo.

76. Tarikh-i-Misr (History of Egypt), pp. 106, 16mo.

77. Firdaus-i-Gumshuda (Milton's Paradise Lost), translated by Isa Charan Saba, pp. 404, 8 vo.

78. Aql bar dawa-i-Tahrif (On Corruption of Scripture), by Sayed Abdulla Athim.

79. Fauz-ul-Azim (Story of Persecution), by Rev. E. M. Wherry, D. D., pp. 100,8 vo.

8o. Haqiqi Irfan (True Knowledge), by Dr. Imad-ud-Din.

81. Izhar-i-Iswi (Christian Declarative), by Rev. G. L. Thakur Das.

82. Izalat ul Mazaru Qadiani (In Refutation of the Qadiani Mirza).

83. Minar-ul-Hang (Pillar of Truth), translated by Mr. Fazl.

84. Muhammad Ke-Karamat (Muhammad wrought no miracles), by Rev. G. L. Thakur Das.

85. Naqma Tamburi (A Song of a Drum), Refutation of Ahmadi Claims, by Dr. Imad-ud-Din.

86. Review-i-Burkhan-i-Ahmadi (An Exposure of Ghulan Ahmad of Qadian.)

87. Salasat-ul-Kutub (On the Holy Trinity).

88. Tahqiq ul Iman (Investigation of the Faith), by Rev. Imad-udDin, D. D.

89. Jang $\mathrm{i}$ Badr o Ukad (Battles of Badr and Uhud), by Canon $E$. Sell, pp. 80, Royal I6mo.

90. Al Quran (The Quran,) by Canon E. Sell, pp. 60, Royal 16mo.

91. Kashf-ul-Quran (Historical Development of the Quran), by Canon E. Sell.

92. Asül-o-Faru (Roots and Branches), by Rev. Dr. Potter of Teheran, translated by Prof. Muhammad Ismail (In press).

\section{EVANgElistic Tracts}

Many tracts are written in Urdu which address men in general and are useful among Moslems: e.g.

I. Adam where art thou? (Moody)

2. The Atonement (Goldsack)

3. Twenty tracts by Rev. G. H. Rouse for special use among Moslems: The Names of God-The Sinless Prophet-The Paraclete-The Fatiha-Isaac and Ishmael-The Day of Judgment-God Our Father-The Ten Commandments of God-Are the Gospels Abrogated?-Prophecies Concerning Christ-Christ or Mohammad-On Prayer-Jesus Christ-On Fasting-On Mohammad-Integrity of the Gospels-The Quran-The True Islam-The Death and Resurrection of Jesus Christ. 
23. On $\operatorname{Sin}$ (A. E. Day).

24. The Confession of Peter (Lucas).

24. The Sermon on the Mount.

25. What is it to Get Salavation?

26. On Holiness.

27. Law and Grace (Newton).

28. The Nature of Repentance.

In addition to these there are tracts on social service, temperance, purity, etc.

The Literature needed for Moslems in the New Era is two-fold :

(a) A Spiritual literature addressed to men, not as Moslems, or Hindus, but as sinners needing to be reconciled to God and filled by His Spirit.

(b) A Scriptural apologetic, holding up Jesus Christ as the Saviour of the world whose law of liberty must become the only law of life.

This will necessitate a revision of much of the litcrature already published for the defense of the faith and for the overthrow of Islam. In its day that literature has not been useless. It was largely forced upon us by the Moslcms themselves. Moslem converts like Maulvé Imad ud Din, Sayed Abdulla Athim, Talib udDin, J. Qalandar, Safdar Ali, met their antagonists on their own ground and defeated them. Naturally other Indian Christians took up the same weapons. Men like G. L. Thakur Das, Fazl Babu Ram Chandar, and Thomas Howell became recognized champions of the Christian faith. On the European side a more learned polemic was maintained. Sir William Muir, Canon E. W. Sell, Dr. St. Clair Tisdall, G. H. Rouse and others have practically covered the whole sphere of controversy with Orthodox Islam, from the standpoint of Orthodox Islam; heterodox movements have risen so that now the champions of Islam belong to the ranks of the Ahmadiya and Baha'i sects. These are being met by Christian writers. But the New Era movement now inaugurated depends more upon an earnest endeavor to circulate widely the word of God and by personal work with individuals persuade them to read the Bible and especially the Gospels. This with a spiritual literature setting forth the life and doctrine of Christ will 
avail to turn multitudes of Moslems into the way of the Church of the Living God. A great deal of good is being done through the English language by the publications of the Christian Literature Society for India (Islam Series). Such writers as Canon Sell, E. M. Wherry, Wm. Goldsack, J. Takle, H. J. Lane Smith, H. U. W. Stanton, J. J. Lucas, H. D. Griswold and Siraj ud Din, have done excellent work.

The new literature for Moslems will include, Urdu Commentaries on the four Gospels and Acts, written for the Moslem mind; an Urdu work on the Holy Spirit (modelled on Christian Dynamic) by J. F. Edwards; works on Jesus in History, Jesus in Life (McFadyen); The Fact of Christ (P. Carnegie Simpson) ; Christ and Womanhood; Christ and the Children or Christ and the Home. A long list of tracts dealing with Practice and Religion, Christian Graces, Temperance and Social Service, etc.

This literature should be prepared during a period of seven to ten years and would approximately cost, I estimate, about $R_{15,000}$ annually.
Ludhiana, India.
E. .11. IIIMis:. 